\title{
CHEMICAL AND BIOLOGICAL APPROACHES FOR IMPROVING WHEAT PRODUCTIVITY UNDER SALINE SODIC SOIL CONDITIONS

\author{
Abbas, H. H. ${ }^{1}$; M. E. Ali ${ }^{1}$; Kh. A. Shaban ${ }^{2}$ and M. I. Mohaseb ${ }^{2}$ \\ 1- Fac. of Agric. Benha Univ. Egypt. \\ 2- Soil, Water and Environ . Inst. , ARC., Giza, Egypt.
}

\begin{abstract}
The current work represents a trial towards improving wheat productivity grown on a saline sodic soil in El-Tina plain, North Sinai. Fulfilling such an objective was executed through three approaches all of them aim at increasing the plant tolerance for salinity. The first approach involved supplying the plant with its $\mathrm{N}$ requirement from different sources i.e. readily available $N$ (urea), slow release $N$ fertilizers i.e. urea formaldehyde and sulfur coated urea each at a rate of $114 \mathrm{~kg} \mathrm{~N}$ ha ${ }^{1}$ beside of a compost of plant residues at a rate of $>119 \mathrm{mg} \mathrm{ha}^{-1}$. The second approach involved inoculating the wheat seeds with Azospirillium brasilence No. 40 (salt tolerant bacteria) while the third approach involved spraying the grown plants

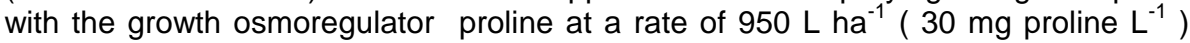
Results revealed that the studied approached could succeed when applied solely in increasing wheat yield and its attributes, however, the combined treatment of applying compost, inoculation with Azospirillium sp and spraying the grown plants with proline was extremely important for maximizing grain yield and increasing uptake of the different nutrtive elements i.e. N, P, K, Fe, Mn and Zn.
\end{abstract}

Keywords: chemical, biological approaches, weat, saline sodic soils.

\section{INTRODUCTION}

Wheat is one of the strategic crops (Gad and Kandil, 2011), probably the most important crop in Egypt (McVey et al., 2004). The domestic production of wheat is not sufficient to cover the public needs, consequently the Egyptian government imports around 7.15 million tons annually to insure public food security and at the same time, support land reclamation strategies for increasing the domestic production of wheat on the long run (Shehata and Mohammed, 2010). On the other hand, soil salinity has become one of the main features in the newly reclaimed soils (Sakadevan and Nguyen, 2010) and even in the Nile delta (Kotb et al., 2000). This problem arises mainly from soil aridity and the preset share for the Egyptian government in the Nile water (El-Agha et al., 2011) . Soil salinity lowers the total soil-water potential and limits water mobility and flux by plant roots (Munns, 2010; Sucre and Suárez, 2011), thus induces drought conditions for the grown plants (Ramoliya et al., 2004). This stress could affect negatively plant growth parameters and reduces the yield quality of the outcome product (Barbieri et al., 2011). One of the main approaches for increasing plant tolerance for the saline conditions is inoculating plant seeds with halophytic growth promoting rhizobacterium of Azospirillum brasilense which can symbiotically live with the grown plant (Zarea et al., 2012). Also, utilization of growth osmo-regulator proline can 
reduce the negative impacts of soil salinity (Abd El-Samad et al., 2010; Manjili et al., 2012 and Sakr et al., 2012).

The current research aimed at studying the effects of Azospirillum brasilense as well as the effect of proline under differet $\mathrm{N}$ sources on wheat plant and increasing its productivity.

\section{MATERIALS AND METHODS}

\section{Site description}

The area of study is located at Sahl-El-Tina Plain, North Sinai between $32^{\circ}: 35^{\circ}$ and $32^{\circ}: 45^{\circ} \mathrm{E}$ and $31^{\circ}: 00^{\circ}$ and $31^{\circ}: 250 \mathrm{~N}$. A representative surface soil sample $(0-30 \mathrm{~cm})$ was collected from the studied area during the winter season of $2011 / 2012$. Analysis the soil was a saline sodic sandy clay, moderatly alkalive ( Table 1 ).

Table 1: Physical and chemical properties of soil of the study.

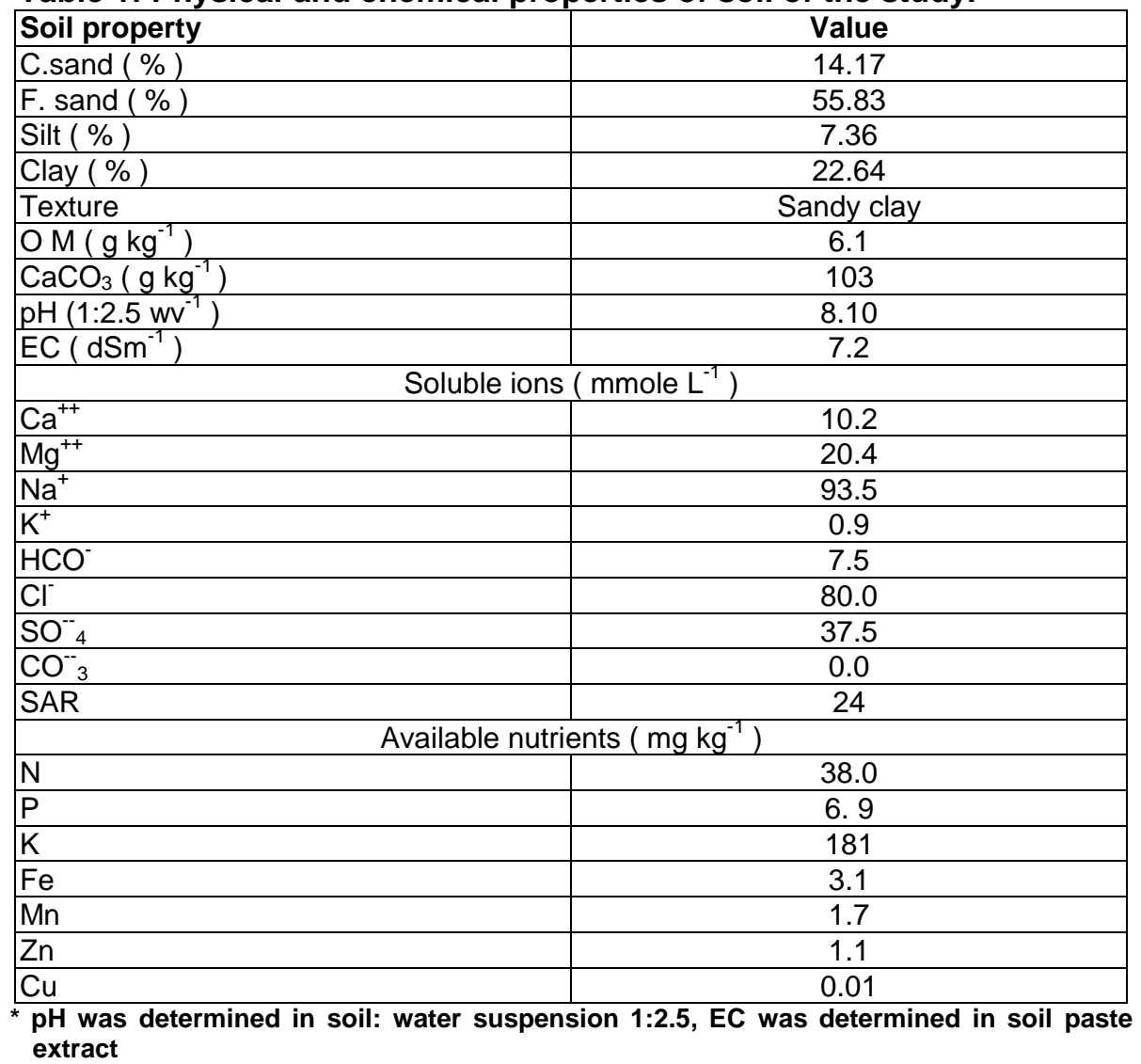

This area is irrigated with El-Salam Canal water (Nile water mixed with agricultural drainage water at a ratio of 1:1). The chemical characteristics of the irrigation water during October 2011 to May 2012 are shown in Table 2. 
Table 2: Chemical characteristics of El-Salam canal irrigation water during summer and winter of 2011/ 2012.

\begin{tabular}{|l|c|c|c|c|c|}
\hline Property & \multicolumn{5}{|c|}{ Month } \\
\hline & Oct. & Dec. & Feb. & Apr. & May \\
\hline $\mathrm{pH}$ & 8.14 & 8.17 & 8.21 & 8.10 & 8.22 \\
\hline $\left.\mathrm{EC}(\mathrm{dS} \mathrm{m})^{-1}\right)$ & 1.03 & 1.18 & 1.25 & 1.20 & 1.27 \\
\hline $\mathrm{SAR}$ & 4.22 & 4.31 & 4.41 & 4.29 & 4.56 \\
\hline $\mathrm{NO}_{3}{ }^{-} \mathrm{N}\left(\mathrm{mgL}^{-1}\right)$ & 7.25 & 7.44 & 8.20 & 8.41 & 9.41 \\
\hline $\mathrm{NH}_{4}{ }^{-1}\left(\mathrm{mgL}^{-1}\right)$ & 12.78 & 13.28 & 13.45 & 13.41 & 14.16 \\
\hline $\mathrm{P} \quad\left(\mathrm{mLL}^{-1}\right)$ & 3.69 & 4.55 & 5.71 & 5.60 & 4.93 \\
\hline $\mathrm{K} \quad\left(\mathrm{mgL}^{-1}\right)$ & 6.21 & 6.35 & 6.51 & 6.46 & 7.19 \\
\hline $\mathrm{Fe} \quad\left(\mathrm{mgL}^{-1}\right)$ & 1.96 & 2.33 & 2.47 & 2.31 & 3.16 \\
\hline $\mathrm{Mn}\left(\mathrm{mgl}^{-1}\right)$ & 1.16 & 1.46 & 1.52 & 1.27 & 1.68 \\
\hline $\mathrm{Zn}\left(\mathrm{mgL}^{-1}\right)$ & 0.90 & 0.96 & 0.98 & 1.03 & 1.23 \\
\hline
\end{tabular}

\section{Materials of study}

1-An inoculum of the salt tolerant "Azospirillum braislense No.40" bacteria in a water suspension (supplied by the Microbiology Department, Soil. Water and Environment Research Institute, of the Agricultura Reseach Center " ARC ", Giza, Egypt ).

2- The growth osmo-regulator proline at a concentration of $30 \mathrm{mgL}^{-1}$

3- Compost of plant residues the chemical properties of which are shown in Table 3.

4- The Nitrogen fertilizer sourcec of urea $\left(460 \mathrm{~g} \mathrm{~N} \mathrm{~kg}^{-1}\right)$, urea formaldehyde $\left(400 \mathrm{~g} \mathrm{~N} \mathrm{~kg}^{-1}\right)$ sulfur coated urea $\left(400 \mathrm{~g} \mathrm{~N}^{2}\right.$ and $\left.170 \mathrm{~g} \mathrm{~S} \mathrm{~kg}^{-1}\right)$;

5- Seeds of wheat (Triticum aestivum C.v Sakha 93) supplied by the Field Crops Research Institute ARC.

Table 3: Chemical properties of the compost under study.

\begin{tabular}{|l|c|}
\hline Parameter & Vaue \\
\hline $\mathrm{EC}$ & $4.21 \mathrm{dSm}$ \\
\hline $\mathrm{pH}$ & 7.2 \\
\hline Moisture content \% & $25 \%$ \\
\hline Nutrentes & $\mathrm{kg}^{-1}$ \\
\hline $\mathrm{O} \mathrm{M}$ & $448.7 \mathrm{~g} \mathrm{~kg}^{-1}$ \\
\hline $\mathrm{C} / \mathrm{N}$ ratio & 9.1 \\
\hline $\mathrm{O} \mathrm{C}$ & 260 \\
\hline $\mathrm{N}$ & $28.6\left(\mathrm{~g} \mathrm{~kg}^{-1}\right)$ \\
\hline $\mathrm{P}$ & $8.0\left(\mathrm{~g} \mathrm{~kg}^{-1}\right)$ \\
\hline $\mathrm{K}$ & $1.57\left(\mathrm{~g} \mathrm{~kg}^{-1}\right)$ \\
\hline $\mathrm{Fe}$ & $230\left(\mathrm{mg} \mathrm{kg}^{-1}\right)$ \\
\hline $\mathrm{Mn}$ & $80\left(\mathrm{mg} \mathrm{kg}^{-1}\right)$ \\
\hline $\mathrm{Zn}$ & $115\left(\mathrm{mg} \mathrm{kg}^{-1}\right)$ \\
\hline $\mathrm{Cu}$ & $44\left(\mathrm{mg} \mathrm{kg}^{-1}\right)$ \\
\hline
\end{tabular}

pH and EC were determined in compost suspension 1:2.5. 


\section{The field study}

A field experiment was conducted during the winter season of 2011/2012. The experimental design was a randomized complete block with three factors:

(1) N- sources no N appication " $\mathrm{N}_{0}$ " The factors and their treatments were as follows: urea " $\mathrm{N}_{1}$ ", urea formaldehyde " $\mathrm{N}_{2}$ ", sulfur coated urea " $\mathrm{N}_{3}$ " and compost " $\mathrm{N}_{4}$ ". The rate of $\mathrm{N}$ was $114 \mathrm{~kg} \mathrm{ha}^{-1}$.

(2) Biofertilization : no biofertilization " $\mathrm{B}_{0}$ " and biofertilization by inoculation with "Azospirillum braislense No.40" " $\mathrm{B}_{1}$ " ( $1 \mathrm{~mL}$ contain $3 \times 10^{9}$ bacterial cell ) which was used for inoculation of wheat seeds at a rate of $2.4 \mathrm{~kg} \mathrm{ha}$ 1 and then sprayed on the soil beside the plant roots at 30 and 60 days after seeding at a rate of $12 \mathrm{~L} \mathrm{ha}^{-1}$.

(3) Proline spray : no spray " $P_{0}$ " and foliar spray with proline " $P_{1}$ " The rate of spray was 950 Lha $^{-1}$.

(4) Compost was added at a rate of $11.9 \mathrm{Mgha}^{-1} 25$ days before seeding, half the amount of compost was incorporated into the soil before ploughing and the other half was applied after pluwing followed by thoroug harrowing to be mixed thoroughly with the $5-\mathrm{cm}$ soil surface. The preparation of compost was done using a quantity of $5000 \mathrm{~kg}$ of an airdry mixture of shredded plant residues of wheat straw, rice straw, faba bean straw and maize stover. About $300 \mathrm{~kg}$ of well decomposed farmyard manure was thoroughly mixed with the mixture to enhance microbial activity, then made into heaps each of about 8 layers. The heaps were moistened with sufficient water. Every 21 days, they were turned over and thoroughly mixed (3 turns) until the obtained compost was well decomposed. Detailed operations on composting are given by Shaban (2005).

Total number of plots of the experiment was 60 ( 2 "biofertlization" $X$

(5) " N treatmente" X 2 "proline treatmente" X 3 replecates ). The plot area was $6 \mathrm{~m}^{2}$. On the 15th of October 2011 seeds of wheat (Triticum aestivum, c.v. Sakha 93) were sown at a rate of $144 \mathrm{~kg} \mathrm{ha}^{-1}$. The soil of the experiment received calcium super-phosphate $\left(67.7 \mathrm{~g} \mathrm{P} \mathrm{kg}^{-1}\right)$ at a rate of $16 \mathrm{~kg} \mathrm{Pha}^{-1}$ during soil preparation, while potassium sulphate $(400 \mathrm{~g} \mathrm{~K}$ $\mathrm{kg}^{-1}$ ) at a rate of $236 \mathrm{kgha}^{-1}$ was added in 3 equal splits 21, 42 and 62 days of planting. Wheat was harvested on the $25^{\text {th }}$ of May 2012 (when moisture of grains was about 12\%). Grain samples were taken determining NPK contents.

\section{Laboratory : \\ Analyses:}

Particle size distribution, $\mathrm{CaCO}_{3}$ content, organic matter content , $\mathrm{pH}$, $\mathrm{EC}$ and soluble ions and available nutrients were determined in soil. Plant compost and water samples were also determined. Extractions of available nutrients were by $0.5 \mathrm{~m} \mathrm{KCl}$ ( for $\mathrm{N}$ ), ammonium bicarbonato "AB-DTPA ( for $\mathrm{P}, \mathrm{K}, \mathrm{Fe}, \mathrm{Mn}, \mathrm{Zn}$ and $\mathrm{Cu})$. Methods of analyses were according to those cited by Klute (1986), Page et al .(1982) and Soltanpour (1985).

Plant analyses:

Dried plant sample was wet digested using. 


\section{RESULTS}

Effect of $\mathrm{N}$-source, bio-fertilization and proline on wheat grain yield and NPK uptake.

\section{Effects on wheat grain yield}

Table 4 shows that proline and the bio-fertilizer increased wheat grain yield significantly. Both of them, the combined treatment caused more increases in wheat grain yield than did the single treatments. Sulfur-coated urea and compost recorded the highest increases caused by $\mathrm{N}$-source, whereas urea recorded the lowest increase.

Table 4: Wheat grain yield $\left(\mathrm{Mg} \mathrm{ha}^{-1}\right)$ as affected by $\mathrm{N}$-fertilizer, compost, bio-fertilizer and proline spray.

\begin{tabular}{|c|c|c|c|c|c|c|c|}
\hline Proline & Bio & & & - Sour & & & Mnon \\
\hline & fertilizer & $\mathrm{N}_{0}$ & $\mathrm{~N}_{1}$ & $\mathrm{~N}_{2}$ & $\mathrm{~N}_{3}$ & $\mathrm{~N}_{4}$ & viean \\
\hline & $\mathrm{B}_{\mathrm{o}}$ & 2.67 & 2.87 & 2.99 & 3.88 & 4.45 & 3.37 \\
\hline$P_{0}$ & $\mathrm{~B}_{1}$ & 3.05 & 3.55 & 4.29 & 4.44 & 4.59 & 3.98 \\
\hline & mean & 2.86 & 3.21 & 3.64 & 4.16 & 4.52 & 3.67 \\
\hline & $\mathrm{B}_{0}$ & 3.19 & 3.39 & 3.76 & 3.91 & 5.79 & 4.00 \\
\hline$P_{1}$ & $B_{1}$ & 3.79 & 4.09 & 5.55 & 5.76 & 5.92 & 5.02 \\
\hline & mean & 3.49 & 3.74 & 4.65 & 4.83 & 5.85 & 4.51 \\
\hline Gra & mean & 3.17 & 3.47 & 4.15 & 4.49 & 5.18 & \\
\hline & & ans of & fertiliz & $(B)$ & & & Mean \\
\hline & & 2.93 & 3.13 & 3.37 & 3.89 & 5.12 & 3.68 \\
\hline & & 3.42 & 3.82 & 4.92 & 5.11 & 5.25 & 4.50 \\
\hline $\begin{array}{l}\text { LSD : } \\
\text { NBP }=0.0 \\
\text { N source } \\
\text { N4 :com } \\
\text { ffect or }\end{array}$ & $0:$ no $N$ & rain & $P=0 . C$ & $\mathrm{NB}=$ & $97, \mathrm{~N}$ & $\begin{array}{l}0097, \\
\text { r Coat }\end{array}$ & $\begin{array}{l}=0.0060 \\
\text { Urea anc } \\
\text { e. }\end{array}$ \\
\hline
\end{tabular}

Table 5 illustrates that proline increased the 1000 grain weight and such increases were more pronounced with inoculation. On the other hand, $\mathrm{N}$-source in the form of sulfur-coated urea and compost recorded the highest increases in the 1000-wheat grain yield.

The aforementioned results reveal that application of compost as a source for $\mathrm{N}$ increases grain yield as well as the 1000- wheat grain weight. This finding is probably due to its amending effect on soil properties decomposition of the organic compost beside $\mathrm{CO}_{2}$ formed and dissolved forming $\mathrm{H}_{2} \mathrm{CO}_{3}$ which would decrease soil $\mathrm{pH}$ and makes plant nutrients elements more available. Also, compost as an organic amendment may acts as a cementing agent for the soil particles and hence encourages formation of soil aggregates. 
Table 5: 1000- wheat grain weight as affected by $\mathrm{N}$-source, bio-fertilizer and proline.

\begin{tabular}{|c|c|c|c|c|c|c|c|}
\hline Proline & & & & - Sour & & & Morn \\
\hline & fertilizer & $\mathrm{N}_{0}$ & $\mathrm{~N}_{1}$ & $\mathrm{~N}_{2}$ & $\mathrm{~N}_{3}$ & $\mathrm{~N}_{4}$ & TVIedu \\
\hline & $\mathrm{B}_{0}$ & 22.33 & 27.00 & 32.00 & 36.67 & 38.67 & 31.33 \\
\hline$r_{0}$ & $B_{1}$ & 29.33 & 37.67 & 41.00 & 48.00 & 51.00 & 37.60 \\
\hline & mean & 25.83 & 32.33 & 36.50 & 42.33 & 44.83 & 36.37 \\
\hline & $\mathrm{B}_{0}$ & 26.33 & 30.00 & 36.67 & 45.67 & 49.33 & 41.40 \\
\hline$P_{1}$ & $\mathrm{~B}_{1}$ & 33.33 & 39.67 & 44.00 & 49.67 & 53.00 & 43.93 \\
\hline & mean & 29.83 & 34.83 & 40.33 & 47.67 & 51.17 & 40.77 \\
\hline Grand $n$ & & 27.83 & 33.58 & 38.42 & 45.00 & 48.00 & \\
\hline & & & leans $c$ & io ferti & $r(B$ & & Mean \\
\hline $\mathrm{B}_{0}$ & & 24.33 & 28.50 & 34.33 & 41.17 & 44.00 & 34.47 \\
\hline $\mathrm{B}_{1}$ & & 31.33 & 38.67 & 42.50 & 48.83 & 52.00 & 42.67 \\
\hline
\end{tabular}

\section{Effect on NPK uptake by wheat grains Effect on $\mathrm{N}$-uptake}

The results presented in Table 6 show that $\mathrm{N}$-uptake by grains were significantly affected by spraying wheat with the osmo-regulator -proline and also with inoculation. Also, the source of $\mathrm{N}$ increased $\mathrm{N}$-uptake, especially the compost source followed by the sulfur coated urea.

Table 6: $\mathrm{N}$ uptake $\left(\mathrm{kg} \mathrm{ha}^{-1}\right)$ by wheat grains as affected by $\mathrm{N}$-source , bio-fertilizers and proline spray.

\begin{tabular}{|c|c|c|c|c|c|c|c|}
\hline Proline & \multirow{2}{*}{$\begin{array}{l}\text { Bio } \\
\text { fertilizer }\end{array}$} & \multicolumn{5}{|c|}{$\mathbf{N}$ - Source } & \multirow{2}{*}{ Mean } \\
\hline \multirow{4}{*}{$P_{0}$} & & $\mathbf{N}_{0}$ & ${ }_{1} \mathbf{N}$ & ${ }_{2} \mathbf{N}$ & ${ }_{3} \mathbf{N}$ & ${ }_{4} \mathbf{N}$ & \\
\hline & $\mathrm{B}_{0}$ & 49.60 & 56.53 & 61.35 & 79.22 & 94.69 & 68.28 \\
\hline & $\mathrm{B}_{1}$ & 58.36 & 72.44 & 88.28 & 94.58 & 99.89 & 82.71 \\
\hline & mean & 53.98 & 64.49 & 74.82 & 86.90 & 97.29 & 75.49 \\
\hline \multirow{3}{*}{$P_{1}$} & $\mathrm{~B}_{0}$ & 60.43 & 67.49 & 76.23 & 82.75 & 123.89 & 82.16 \\
\hline & $\mathrm{B}_{1}$ & 73.54 & 85.48 & 116.12 & 123.84 & 130.73 & 105.94 \\
\hline & mean & 66.99 & 76.49 & 96.18 & 103.29 & 127.31 & 94.05 \\
\hline \multicolumn{2}{|c|}{ Grand mean } & 60.48 & 70.49 & 85.495 & 95.11 & 112.31 & \\
\hline & & \multicolumn{5}{|c|}{ Means of Bio fertilizer ( B ) } & Mean \\
\hline \multicolumn{2}{|l|}{$\mathrm{B}_{0}$} & 55.02 & 62.01 & 68.79 & 80.98 & 109.29 & 75.22 \\
\hline \multicolumn{2}{|l|}{$B_{1}$} & 65.95 & 78.96 & 102.20 & 109.21 & 115.31 & 94.33 \\
\hline
\end{tabular}

LSD :0.05:- $\mathrm{N}=0.645, \mathrm{~B}=0.462, \mathrm{P}=0.462, \mathrm{NB}=\mathrm{0} . \mathrm{s}, \mathrm{NP}=\mathrm{n} . \mathrm{s}$, $\mathrm{BP}=\mathrm{n} . \mathrm{s}$, NBP=n.s

N sources : N0 : no N, N1 :Urea, N2: Urea formaldehyde, N3: Sulfur Coated Urea and $\mathrm{N} 4$ : compost ;biofertilization with moculation seeds with . azosirillum braiseleuse

\section{Effect on P uptake}

Table 7 demonstrates that $P$ uptake increased in plants due to spraying plants with the osmo-regulator proline, bio-treatment or amending soil with a N-source. The organo-treatment seemed to be the most effecient $\mathrm{N}$-source followed by sulfur coated urea, then urea formaldehyde. The diffent 
treatments of the different combinations among these three factors were mostly of positive effect on $\mathrm{P}$ uptake. The treatments which combine seed moculation + proline $+\mathrm{N}$ addetion may be recommended for maximum $\mathrm{P}$ uptake

Table 7: $\mathrm{P}$ uptake $\left(\mathrm{kg} \mathrm{ha}^{-1}\right)$ by grains as affected by $\mathrm{N}$-source , biofertilizer and proline to wheat on a saline sandy clay soil

\begin{tabular}{|c|c|c|c|c|c|c|c|}
\hline Proline & \multirow{2}{*}{$\begin{array}{c}\text { Bio } \\
\text { fertilizer }\end{array}$} & \multicolumn{5}{|c|}{ Source-N } & \multirow{2}{*}{ Mean } \\
\hline \multirow{4}{*}{$P_{0}$} & & $\mathbf{N}_{0}$ & $\mathbf{N}_{1}$ & $\mathbf{N}_{2}$ & $\mathbf{N}_{3}$ & $\mathrm{~N}_{4}$ & \\
\hline & $\mathrm{B}_{0}$ & 9.690 & 10.903 & 12.170 & 17.317 & 20.153 & 14.047 \\
\hline & $\mathrm{B}_{1}$ & 11.997 & 15.743 & 19.717 & 22.943 & 24.020 & 18.884 \\
\hline & mean & 10.843 & 13.323 & 15.943 & 20.130 & 22.087 & 16.465 \\
\hline \multirow{3}{*}{$P_{1}$} & $\mathrm{~B}_{0}$ & 12.003 & 14.220 & 15.770 & 18.347 & 28.753 & 17.819 \\
\hline & $\mathrm{B}_{1}$ & 15.410 & 19.360 & 28.660 & 30.630 & 33.717 & 25.555 \\
\hline & mean & 13.707 & 16.790 & 22.215 & 24.488 & 31.235 & 21.687 \\
\hline \multicolumn{2}{|c|}{ Grand mean } & 12.275 & 15.057 & 19.079 & 22.309 & 26.661 & \\
\hline \multicolumn{7}{|c|}{ Means of Bio fertilizer ( B ) } & Mean \\
\hline \multicolumn{2}{|l|}{$B_{0}$} & 10.847 & 12.562 & 13.970 & 17.832 & 24.453 & 15.933 \\
\hline \multicolumn{2}{|l|}{$\mathrm{B}_{1}$} & 13.703 & 17.552 & 24.188 & 26.787 & 28.868 & 22.220 \\
\hline
\end{tabular}

\section{Effect on $\mathrm{K}$ uptake}

Table 8 demonstrates that $\mathrm{K}$ uptake by wheat grains was significantly increased owing to the treatments biofertilizer inoculation, spraying plants with proline and amending soil with $\mathrm{N}$. The results recommend that the combination of $\mathrm{N}$ as fertilizer or compost, applied biofertilizer inoculant and spraying with proline could incerease $\mathrm{K}$ uptake values by the grains of wheat plants grown an a saline sodic soil.

Table 8: $\mathrm{K}$ uptake $\left(\mathrm{kg} \mathrm{ha}^{-1}\right)$ by grains as affected by $\mathrm{N}$-source, biofertilizer and proline.

\begin{tabular}{|c|c|c|c|c|c|c|c|}
\hline Proline & \multirow{2}{*}{$\begin{array}{c}\text { Bio } \\
\text { fertilizer }\end{array}$} & \multicolumn{5}{|c|}{$\begin{array}{r}\mathrm{N}-\text { source } \\
\end{array}$} & \multirow{2}{*}{ Mean } \\
\hline \multirow{4}{*}{$P_{0}$} & & ${ }_{0} \mathbf{N}$ & ${ }_{1} \mathbf{N}$ & ${ }_{2} \mathbf{N}$ & ${ }_{3} \mathbf{N}$ & ${ }_{4} \mathrm{~N}$ & \\
\hline & $\mathrm{B}_{0}$ & 61.33 & 67.34 & 70.62 & 92.79 & 107.57 & 79.93 \\
\hline & $\mathrm{B}_{1}$ & 71.57 & 84.28 & 103.86 & 109.38 & 114.89 & 96.79 \\
\hline & mean & 66.45 & 75.81 & 87.24 & 101.09 & 111.23 & 88.36 \\
\hline \multirow{3}{*}{$P_{1}$} & $\mathrm{~B}_{0}$ & 74.13 & 79.68 & 90.37 & 94.97 & 143.57 & 96.55 \\
\hline & $\mathrm{B}_{1}$ & 89.58 & 98.70 & 135.53 & 143.36 & 149.26 & 123.29 \\
\hline & mean & 81.86 & 89.19 & 112.95 & 119.17 & 146.42 & 109.92 \\
\hline \multicolumn{2}{|c|}{ Grand mean } & 74.15 & 82.51 & 100.11 & 110.13 & 128.82 & \\
\hline & & \multicolumn{5}{|c|}{ Means of Bio fertilizer ( B ) } & Mean \\
\hline \multicolumn{2}{|l|}{$\mathrm{B}_{0}$} & 67.73 & 73.51 & 80.51 & 93.88 & 125.57 & 88.24 \\
\hline \multicolumn{2}{|l|}{$\mathrm{B}_{1}$} & 80.58 & 91.49 & 119.69 & 126.37 & 132.08 & 110.04 \\
\hline
\end{tabular}

N sources : N0 : no N, N1 :Urea, N2: Urea formaldehyde, N3: Sulfur Coated Urea and N4 :compost ;biofertilization with moculation seeds with azosirillum braiseleuse 


\section{Discussion}

Wheat growth and grain yield are negatively affected under saline conditions (Grewal, 2010). Thus increasing crop tolerance for salinity is an important approach for maximizing the crop yield and (Rana Munns et al., 2006). Minimizing the uptake of nutrients by wheat can improve its growth under the saline conditions (Munns et al., 2012). Three approaches were examined in this study to increase the plant tolerance for soil salinity by inoculation with Azospirillum brasailanse, spraying plants with proline and $\mathrm{N}$ application by mineral and organic sources fulfilled plant needs for nutrients. Proline was found in high concentrations in many plant species as compatible solute under stress conditions (Ashraf et al., 2012; Khan et al., 2009; Lehmann et al., 2010; Szabados and Savouré, 2010). Thus it can be deduced that spraying plants with proline under stress conditions might be affective for increasing plant tolerance for salinity. Results by others indicate that spraying wheat with proline increased the yield and yield components (EL-Mancy, 1994). Inoculating wheat plants with Azospirillum brasilense was found to be effective for improving the growth performance under soil saline conditions ( Nabti et al. (2010). Mechanisms for increasing plant tolerance for salinity is not well understood. It probably improved nutrient and water uptake, growth promotion and stimulation of plant metabolism(Dodd and Pérez-Alfocea, 2012). Azospirillum brasilense is able to fix nitrogen (FibachPaldi et al., 2012) and improve the $\mathrm{N}$ uptake, total biomass and grain yield of wheat plants (Panwar and Singh, 2000). The urea fertilizer seemed to be of relatively less effeciency on growth performance of wheat. Urea is rapidly hydrolyzed in soil into $\mathrm{NH}_{4}{ }^{+}$(Latifah et al., 2011), thus increasing to some extent the soil salinity. and also suffering of plant from salinity. Results by others indicate that nitrate and ammonium amendments were of little effect on wheat growth under saline conditions (Lewis et al., 1989), thus the use of sulfur coated urea can successfully retard urea hydrolysis in soil (Patra et al., 2009), The current results confirm the importance of amending soil with compost to increase plant tolerance to salinity and improve wheat performance. Hussain et al. (2001) found that the compost applied to a sodic soil increased wheat yield.

\section{CONCLUSION}

Inoculation of wheat seeds $+\mathrm{N}$ application " as mineral or organic + inoculation proline spray had more significant positive effects on grain yield and NPK uptake. Their effects in increasing plant tolerance seemed cumulative. Azospirillum bactera accumulated compatible solutes as a mechanism to increase plant tolerance for salinity (Tripathi et al., 1998).

Amending the saline soils with compost is important to mcrease yield of weat .

\section{REFERENCES}

Abd El-Samad, H. M., M.A.K. Shaddad and N. Barakat. 2010. The role of amino acids in improvement in salt tolerance of crop plants. Journal of Stress Physiology \& Biochemistry 6: 25-37. 
Ashraf, M. A., Muhammad, A. and Muhammad, Sh. 2012. Growth stagebased modulation in antioxidant defense system and proline accumulation in two hexaploid wheat (Triticum aestivum L.) cultivars differing in salinity tolerance. Flora - Morphology, Distribution, Functional Ecology of Plants 207: 388-397.

Barbieri, Giancarlo, Antonella .B, Emilio .D, Simona .V and Albino .M 2011. Proline and light as quality enhancers of rocket (Eruca sativa Miller) grown under saline conditions. Scientia Horticulturae 128: 393-400. doi

Dodd, I.C. and F. Pérez-Alfocea 2012. Microbial amelioration of crop salinity stress. J. Exp. Bot. 63: 3415-3428. doi: 0.1093/jxb/ers033

El-Agha, DoaaE, David.J. $M$ and Ashraf.M .G 2011. Performance assessment of irrigation water management in old lands of the Nile delta of Egypt. Irrigation and Drainage Systems 25: 215-236. doi: 10.1007/s10795-011-9116-z

EL-Mancy, M.H.A. 1994. Water management for better use in soil. Ph. D.Thesis Fac., Agric. Zagazig Univ. Egypt.

Fibach-Paldi, Sharon, Saul Burdman and Yaacov .O 2012. Key physiological properties contributing to rhizosphere adaptation and plant growth promotion abilities of Azospirillum brasilense. FEMS Microbiology Letters 326: 99-108. doi: 10.1111/j.1574-6968.2011.02407.x

Gad, N. and H. Kandil 2011. Maximizing the Tolerance of Wheat Plants to Soil Salinity Using Cobalt- 1- Growth and Mineral Composition Journal of Applied Sciences Research 7: 1569-1574.

Grewal . G and Harsharn .S 2010. Water uptake, water use efficiency, plant growth and ionic balance of wheat, barley, canola and chickpea plants on a sodic vertosol with variable subsoil $\mathrm{NaCl}$ salinity. Agricultural Water Management 97: 148-156. doi

Hussain, N., G. Hassan, M. Arshadullah and F. Mujeeb 2001. Evaluation of

amendments for the improvement of physical properties of sodic soil. Intl. J. Agric. Bio. 3: 319-322.

Khan, M.A., M.U. Shirazi, M. Alikhan, S.M. Mujtaba, E. Islam, S. Mumtaz,A. Shereen, R.U. ANSARI and M.Y. ASHRAF 2009. Role of Proline, K/Na ratio and chlorophyll content in salt tolerance of wheat (Triticum aestivum L.). Pak. J. Bot 41: 633-638.

Klute, A. 1986. Part 1. Physical and mineralogical methods. In Part 1. Physical and mineralogical methods, ed. 2nd, Methods of soil analysis, 1358. Madison, Wisconsin USA: ASA-SSSA-Agronomy.

Kotb, Tarek H. S., Tsugihiro .W, Yoshihiko .O and Kenneth. K.T. 2000. Soil salinization in the Nile Delta and related policy issues in Egypt. Agricultural Water Management 43: 239-261. doi:

Latifah, O., O.H. Ahmed and A.M.N. Muhamad 2011. Reducing ammonia loss from urea and improving soil exchangeable ammonium and available nitrate in non waterlogged soils through mixing zeolite and sago (Metroxylon sagu) waste water International Journal of the Physical Sciences 6: 866-870.

Lehmann. S, Dietmar .F, László .S and Doris .R .2010. Proline metabolism and transport in plant development. Amino Acids 39: 949-962. doi: 10.1007/s00726-010-0525-3 
Lewis, O. A. M., E. O. Leidi and S. H. Lips 1989. Effect of nitrogen source on growth response to salinity stress in maize and wheat. New Phytologist 111: 155-160. doi: 10.1111/j.1469-8137.1989.tb00676.x

Manjili. F. A, Mohammad. S and Mohammad. P. 2012. Effects of photohormones on Proline content and antioxidant enzymes of various wheat cultivars under salinity stress. Journal of Plant Nutrition 35: 1098-1111. doi: 10.1080/01904167.2012.671411

McVey, D. V., M. Nazim, K. J. Leonard and D. L. Long 2004. Patterns of virulence diversity in Puccinia triticina on Wheat in Egypt and the United States in 1998-2000 Plant Dis. 88: 271-279.

Munns. R.2010. Approaches to Identifying Genes for Salinity Tolerance and the Importance of Timescale. In Approaches to Identifying Genes for Salinity Tolerance and the Importance of Timescale, ed. Ramanjulu Sunkar, Plant Stress Tolerance, 25-38: Humana Press.Munns. R, Richard. A. J, Bo Xu. A. Athman, Simon J. Conn,

Charlotte Jordans, Caitlin S. Byrt, Ray A. Hare, Stephen D. Tyerman, Mark Nabti. E, Mohamed. S, Mostefa. G, Doreen. F, Andreas. H, Michael. R,

Michael. S and Anton. H 2010. Restoration of Growth of Durum Wheat (Triticum durum var. waha) Under Saline Conditions Due to Inoculation with the Rhizosphere Bacterium Azospirillum brasilense $\mathrm{NH}$ and Extracts of the Marine Alga Ulva lactuca. Journal of Plant Growth Regulation 29: 6-22. doi: 10.1007/s00344-009-9107-6

Page, A.L., R. H. Miller and D.R. Keeney 1982. "Methods of soil analysis"Part II Chemical and microbiological properties Madison, USA: ASA-SSSA. Agronomy.

Panwar, J.D. and O. Singh 2000. Response of Azospirillium and Bacillus on growth and yield of wheat under field conditions. ndia. J Plant. Physiol.5: 108- 110.

Patra. D.D, Usha. K, Sukhmal. C and Mohd. A 2009. Use of urea coated with natural products to inhibit urea hydrolysis and nitrification in soil. Biology and Fertility of Soils 45: 617-621. doi: 10.1007/s00374-0090372-0

Ramoliya, P. J., H. M. Patel and A. N. Pandey 2004. Effect of salinization of soil on growth and macro- and micro-nutrient accumulation in seedlings of Salvadora persica (Salvadoraceae). Forest Ecology and Management 202: 181-193. doi

Rana. M. R., R.A. James and A. Lauchli 2006. Approaches to increasing the salt tolerance of wheat and other cereals. Journal of Experimental Botany 57: 1025-1043. doi: 10.1093/jxb/erj100

Sakadevan, K. and M. Nguyen 2010. Extent, impact, and response to soil and water salinity in arid and semi arid regions. Advances in Agronomy 109: 55-74. doi: 10.1016/S0065-2113(10)09002-4

Sakr. M.T, Naser.M. El and Michael.P. F. 2012. Osmoregulators proline and glycine betaine counteract salinity stress in canola. Agronomy for Sustainable Development 32: 747-754.doi:10.1007/s13593-011-0076-3

Shaban, KH. A. H, 2005. "Effect of different irrigation water resources on properties and productivity of salt affected soils. Ph.D. Thesis, Fac .of. Agric., Monufiya University. Egypt. 
Shaban, Kh.A. and M.N.A. Omar 2006. Improvement of maize yield and some soil properties by using nitrogen mineral and PGPR group fertilization in newly cultivated saline soils. Egypt .J. Soil, Sci. 46: 329342.

Shehata, A.M.A. and S.I. Mohammed 2010. Food security in Egypt. In Food security in Egypt, 32nd Reca Seminar on Reca Seminar, 156-169. New Delhi: Afro-Asia Development Organization (AARDO).

Soltanpour, N. 1985. Use of ammonium bicarbonate- DTPA soil test to evaluate element availability and toxicity . Soil Sci. Plant Anal. , 16 (3):323-338.

Sucre, B. and N. Suárez 2011. Effect of salinity and PEG-induced water stress on water status, gas exchange, solute accumulation, and leaf growth in Ipomoea pes-caprae. Environmental and Experimental Botany 70: 192-203. doi

Szabados. L and Arnould. S 2010. Proline: a multifunctional amino acid. Trends in plant science 15: 89-97.

Tripathi, A. K., B. M. Mishra and P. Tripathi 1998. Salinity stress responses in the plant growth promoting rhizobacteria,Azospirillum spp. Journal of Biosciences 23: 463-471. doi:

Zarea, M. J., S. Hajinia, N. Karimi, E. Mohammadi. G, F. Rejali and A. Varma 2012. Effect of Piriformospora indica and Azospirillum strains from saline or non-saline soil on mitigation of the effects of $\mathrm{NaCl}$. Soil Biology and Biochemistry 45: 139-146. doi:

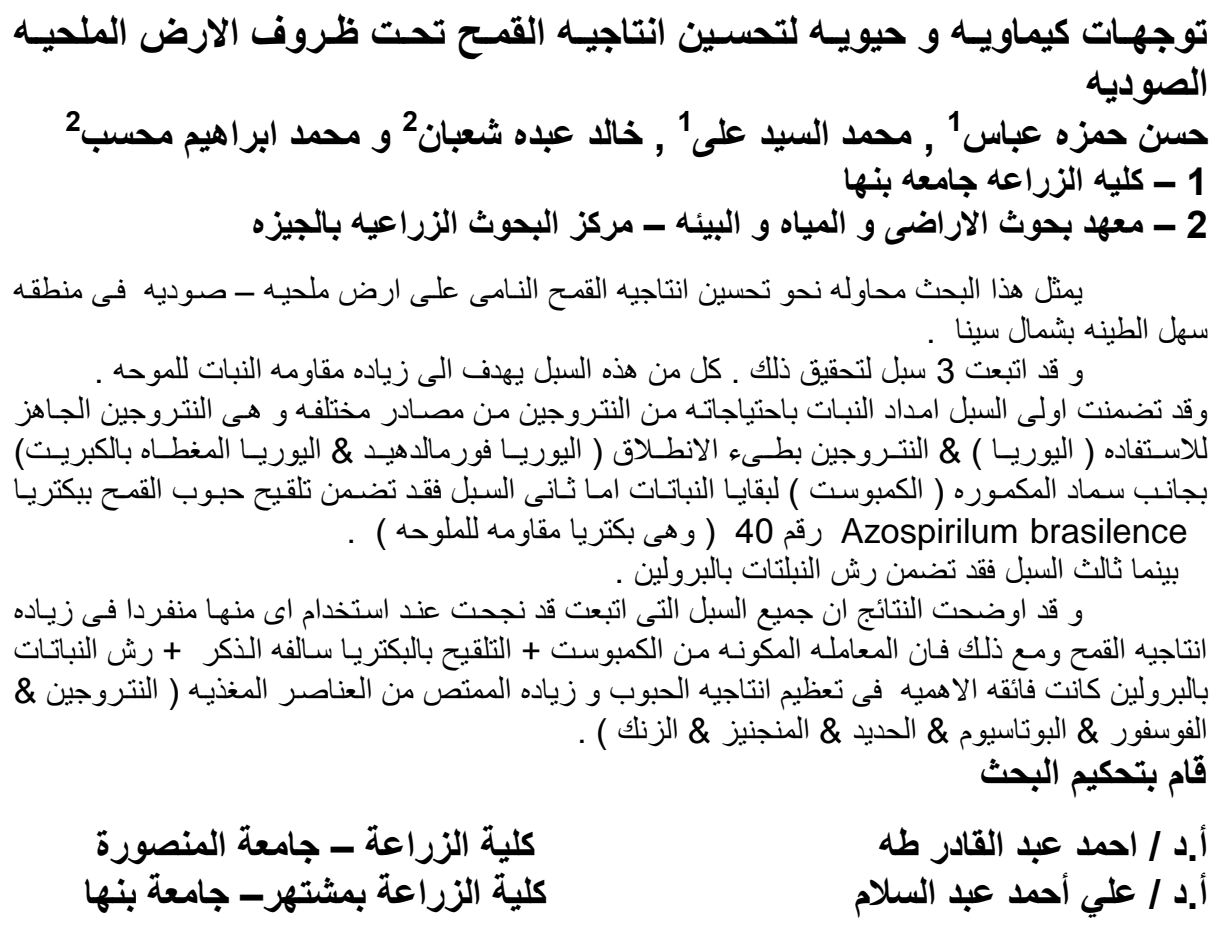

